\title{
EATING HABITS OF ADOLESCENTS IN POLAND AND IN OTHER COUNTRIES
}

\author{
Małgorzata Wasilewska, Józef Bergier
}

\author{
Pope John II State School of Higher Education in Biała Podlaska, Department of Physical Education and \\ Physiotherapy, Faculty of Tourism and Recreation
}

Wasilewska M., Bergier J. (2015), Eating habits of adolescents in Poland and in other countries, Health Problems of Civilization, 4 (9), p. $40-48$.

\begin{abstract}
Summary: The issue of eating behaviour may be considered both from the perspective of medical and social science. Unhealthy eating habits and lack of physical activity (PA) are well known risk factors for the appearance of many chronic diseases in adulthood. Along with sedentary lifestyle they are the main cause of the increasing prevalence of obesity in adolescents. The aim of this paper is to present eating habits of students in light of Polish and international research within different variables. Polish and international research conducted on a possibly large study material were used for comparison. It can be concluded that there are many irregularities with reference to eating behaviours. The most common nutrition mistakes made by teenagers are not eating breakfast and snacking between meals (usually sweets, chips, fast-food products).
\end{abstract}

Keywords: eating behaviours, determinants, adolescents, health behaviours

\section{Introduction}

Eating behaviour is a type of health behaviours and element of a lifestyle (Łuszczyńska 2004). It covers dietary habits and nutrition preserved over a long period of time. It can be specified as all activities related to food and human nutrition, including food choice, shopping organization, storage and preparation, as well as the frequency and regularity of consumption, number of meals, snacking and circumstances of food consumption (Gertig, Gawęcki 2001, Gronowska-Senger 2009, Narojek 1993 after: Harton 2013). Eating behaviour may also include eating during the day certain number of products and meals (Gronowska-Senger 2009 after: Harton 2013).

The issue of eating behaviour may be considered both in the field of medical and social science. Research into eating behaviour can be conducted on many levels: as an important area of health behaviour, as a part of cultivation of tradition or as consumer behaviour (Buczak 2013). Even in ancient times people realised the relationship between eating behaviour and health or disease in humans. Unhealthy eating habits and lack of physical activity (PA) are well known risk factors for the appearance of many chronic diseases in adulthood, such as cardiovascular disease, type 2 diabetes or cancer (Warburton et al. 2006, WHO 2002, Maynard et al. 2003). Along with sedentary lifestyle they are the main cause of the increasing prevalence of obesity in adolescents (Maffeis 2000). Watching TV or, the so called, "screen time" used as main measures of the sedentary lifestyle were not only associated with the consumption of food advertised on television, but also with the consumption of high-energy foods (Must et al. 2009). What is more, such behaviours tend to be transferred from childhood to adulthood (Post et al. 2001, Trudeau et al. 2004).

Puberty is a period of growth and development, bridge connecting childhood with adulthood. Physical and emotional changes that occur during puberty affect eating and health behaviours. Puberty is a potentially critical period for body built later in life and obesity development in adulthood (van Lenthe et al. 1996). It can be caused by hormonal changes regulating appetite, satiety and fat distribution which appears later in adolescence (Lustig 2006). Puberty is also a period of dramatic behavioural changes, during which children are looking for their own identity, trying to be autonomous in their decisions, and these can affect eating behaviours (Lytle, Kubik 2003) and physical activity (Berkey 2000). Eating habits of adolescents are related to their need to express freedom from parental control and to their efforts aiming at the adoption of what they perceive as adult preferences and lifestyle (Thomas 1991). Key features of their eating patterns cover snacking, not eating breakfast, dieting,

Address for correspondence: Małgorzata Wasilewska, Pope John II State School of Higher Education in Biała Podlaska, Sidorska 105, 21-500 Biała Podlaska, phone: +48 8334499 00, e-mail: wasilewskagosia@interia.pl

Tables: 2 Figures: 0 References: 42 Full-text PDF www.hpc.edu.pl Copyright @ Pope John Paul II State School of Higher Education in Biała Podlaska, Sidorska 95/97, 21-500 Biała Podlaska Indexation: Index Copernicus, AGRO, ProQuest, Polish Medical Bibliography, Polish Ministry of Science and Higher Education. This is an open-access article distributed under the terms of the Creative Common Attribution Non-commercial license (http://creativecommons.org/licenses/by-nc/3.0), which permits use, distribution and reproduction in any medium, provided the original works is properly cited, the use is non-commercial and is otherwise in compliance with the license. 
adopting a specific diet (such as vegetarian diet), eating sweets and fast-food products (Shepherd, Dennison 1996; Herbold, Frates 2000). On the other hand, dietary irregularities_at this stage of life not only affect health of adolescents, but also increase the risk of chronic diseases in adulthood (Dietz 1998; Weaver et al. 1999). Therefore, it is important for public heath to implement and maintain healthy eating habits at an early stage of life.

\section{Eating behaviours of older school youth in the light of national and other countries' studies}

The aim of this paper is to present eating habits of students in the light of Polish and international research within different variables. Polish and international research conducted on a possibly large study material were used for comparison. The choice was preceded by a thorough analysis of the research papers available in the electronic databases of EBSCO, Researchgate, SAGE journals, PubMed. What was sought were original papers examining the heating habits of adolescents (aged 16-18). Table 1 shows descriptive summary of selected Polish papers. Table 2 presents selected works from around the world with their first author, the test area, the goal that led the researchers, main conclusions and age of the respondents. During the analysis, the authors encountered difficulties with comparability, which were related to the use of various authors' questionnaires, as well as to different methods of statistical analysis during data calculations. It made it impossible to create a detailed comparison at all levels in terms of eating behaviour. Consequently, it was decided not to make a detailed comparative analysis of different research results but only to present their most important conclusions. Within the context of research on health behaviour, including eating behaviour in children and adolescents, a mention should be made of cyclic HBSC ${ }^{1}$ surveys conducted under the auspices of the WHO. The research shows that girls are characterized by lower frequency of risky health behaviours in comparison with boys. There is a clear tendency for the shortcomings with regard to almost all health behaviours to accumulate with age (http:// www.studio47.com.pl/wartosczdrowia/.... 17.06.2015). The analysis of the results of the subsequent editions of the HBSC studies from years 2002, 2006, 2010 points to an intensification of many negative behaviours related to nutrition, such as less frequent breakfast consumption or more frequent use of slimming diets (MałkowskaSzkutnik et al. 2011 after: Wojtyła et al. 2011 p.20). The indisputable advantage of the HBSC questionnaire is the possibility of comparing the obtained data between many countries, whereas the drawback is restricted adolescents age limit, between 11 and 15 years. There are attempts to use the questionnaire in the research with older youths aged 17-19, e.g. in Ireland in 2006 (http://www.nuigalway.ie/hbsc/documents/... access: 17.06.2015) or in Poland in 2010 (Mazur, Małkowska-Szkutnik 2011). However, they are described as conducted "off the record" and are not included in the international report. Therefore, the authors decided not to include national HBSC research to the compilation, despite a huge temptation carried by the possibility of direct references to international research. They did it also to demonstrate a great need to create a unified measurement tool for eating behaviour in older school youth, aged 16-18, especially because the time of puberty is characterized by instability in the eating habits (Post et al. 2001). Another big problem is also a kind of "festival" of self-designed questionnaires, which results remain without the possibility of comparison. The authors fully agree with Woynarowska's view in the aspect concerning existence of many studies on various aspects of health behaviour in children and adolescents, and difficulties in comparing their results and tracking them due to wide variety of research methods (http://www.studio47.com.pl/wartosczdrowia... access: 17.06.2015). The overview of national publications made by the authors of this paper seems to confirm the thesis.

If we look at the research on eating behaviour among adolescents in Poland, we come to the conclusion that there are many such papers, which proves the importance and popularity of this issue among researchers. Those studies show that health behaviours are very different. This differentiation relates to the environment, age and sex of the respondents, and is conditioned by the social status and education of parents (Wojtyła et al. 2011). The research by Bojar et al. (2010) showed that almost every third child claims he/she was once dieting. Half of the respondents admits having trouble with excessive consumption and $40 \%$ is afraid of gaining weight. About $3 \%$ of junior high school students said they are vegetarian and nearly $70 \%$ likes salty dishes. The diet of adolescents in Poland is too rich in flour products, sweets (daily - 42,3\%) and animal fats (daily - 66,0\%), while too low in fish (less than once a week - 55,9\%; less than once a month/not at all - 15,4\%), vegetables and fruits, milk and products with probiotics. Even $77 \%$ of junior high school students snack during the day. In most cases snacks are fruits (75\%), but unfortunately also to a large extent sweets (65\%), yoghurts (53\%) and cookies (50\%). To

HBSC - Health Behaviour in School-aged Children is an international network of scientists currently uniting 43 countries. These are countries classified by the World Health Organisation (WHO) as belonging to the European region, as well as Canada and USA. Poland took part in six consecutive series in years: 1990 (4643 adolescents surveyed), 1994 (4527 adolescents surveyed), 1998 (4861 adolescents surveyed), 2002 (6383 surveyed), 2006 (5489 surveyed) i 2010 (4809 surveyed). Anonymous survey questionnaire covers three school years, which corresponds to the following classes in Poland: $5^{\text {th }}$ class of elementary school (hereafter the term 11-year-olds is used), $1^{\text {st }}$ and $3^{\text {rd }}$ class of junior high school (13- and 15-year-olds). (www.hbsc.org dostęp (access): 17.06.2015) 
being overweight or obese subjectively admit $63 \%$ of obese children, whereas $35 \%$ of them think that their body built does not diverge from the norm. However, in the group of respondents who are overweight up to $80 \%$ admit that their body built is compatible with the standard. It is quite surprising in the view of the fact that almost all respondents (98\%) answered that you should keep your weight in the normal range. Thus it can be concluded that children are unaware of their own overweight and they do not know the norms defining the correct values.

In the research by Kiciak et al. (2014) in order to evaluate the eating habits of adolescents, levels according to the nominal scale: low, medium and high were adopted. The vast majority of young people demonstrated eating habits at a low level (85\%), whereas the remaining part (15\%) were people with eating habits at a medium level. It was also concluded that for the adopted significance level, chance of eating habits at a medium level is significantly higher in girls (2 times) than in boys. Nearly half (47\%) of teenagers ate most frequently 4 to 5 meals a day. This number of meals was more common in girls than in boys. The authors also noted that one third of the surveyed girls and boys did not snack at all.

When it comes to consumption of fruits and vegetables, it was stated that nearly half of adolescents included such products in their diet and ate them several times a day. Daily lunch consumption was declared by more than a half of the students. The largest percentage of respondents declared consumption of groats less than once a week, about $74 \%$ of girls and $70 \%$ of boys. This trend is quite alarming because the properly arranged menu should include at least 5 servings of grain products, bearing in mind to choose the products from the so called coarse grinding as they are the source of valuable vitamins, fiber and minerals.

Table 1. Summary of the selected Polish research on the eating behaviours of school-aged adolescents

\begin{tabular}{|c|c|c|c|c|c|c|}
\hline First author & Place of research & $\begin{array}{c}\text { Year of } \\
\text { research }\end{array}$ & Aim of research & Measuring tool & Conclusions & $\begin{array}{c}\text { Age } \\
\text { (in years) }\end{array}$ \\
\hline $\begin{array}{l}\text { Bojar I. et al. } \\
(2010)\end{array}$ & $\begin{array}{l}\text { territorial differ- } \\
\text { entiation in junior } \\
\text { high schools } \\
\text { location within } \\
\text { the country }\end{array}$ & 2009 & $\begin{array}{l}\text { analysis of eat- } \\
\text { ing behaviours } \\
\text { of adolescents in } \\
\text { Poland }\end{array}$ & $\begin{array}{l}\text { author's ques- } \\
\text { tionnaire }\end{array}$ & $\begin{array}{l}\text { diet of adolescents in } \\
\text { Poland is too rich in } \\
\text { flour products, sweets } \\
\text { and animal fats, whereas } \\
\text { too low in fish, vegeta- } \\
\text { bles and fruits, milk and } \\
\text { products with probiotics }\end{array}$ & $17-19$ \\
\hline $\begin{array}{l}\text { Kiciak B. et } \\
\text { al. (2014) }\end{array}$ & $\begin{array}{l}\text { cities of Silesian } \\
\text { Province (Bytom, } \\
\text { Piekary Śląskie, } \\
\text { Radzionków, Tar- } \\
\text { nowskie Góry) }\end{array}$ & $\begin{array}{c}2010- \\
2012\end{array}$ & $\begin{array}{l}\text { assessment of } \\
\text { nutritional atti- } \\
\text { tudes of young } \\
\text { people from } \\
\text { selected schools }\end{array}$ & $\begin{array}{l}\text { author's ques- } \\
\text { tionnaire }\end{array}$ & $\begin{array}{l}\text { significant differences } \\
\text { in eating behaviours } \\
\text { between groups of girls } \\
\text { and boys were demon- } \\
\text { strated; inappropriate } \\
\text { eating habits were found } \\
\text { in a studied group of } \\
\text { people }\end{array}$ & $16-18$ \\
\hline $\begin{array}{l}\text { Sochacka } \\
\text {-Tatara E. et } \\
\text { al. }(2010)\end{array}$ & Kraków & 2010 & $\begin{array}{l}\text { recognition of } \\
\text { the eating habits } \\
\text { of adolescents } \\
\text { and establishing } \\
\text { the scale of po- } \\
\text { tential problems } \\
\text { connected to } \\
\text { them }\end{array}$ & $\begin{array}{l}\text { author's ques- } \\
\text { tionnaire }\end{array}$ & $\begin{array}{l}\text { less than a half of the } \\
\text { studied adolescents de- } \\
\text { clared eating } 5 \text { meals a } \\
\text { day; the most overlooked } \\
\text { ones were afternoon } \\
\text { tea and lunch, but up to } \\
10.3 \% \text { of respondents } \\
\text { did not eat breakfast, } \\
\text { which was particularly } \\
\text { evident among students } \\
\text { of junior high school and } \\
\text { professional technical } \\
\text { school }\end{array}$ & $16-19$ \\
\hline
\end{tabular}




\begin{tabular}{|c|c|c|c|c|c|c|}
\hline $\begin{array}{l}\text { Chęcińska Z. } \\
\text { et al. (2013) }\end{array}$ & Poznań & 2011 & $\begin{array}{l}\text { comparison of } \\
\text { the lifestyle } \\
\text { of adolescents } \\
\text { coming from the } \\
\text { rural and urban } \\
\text { environments as } \\
\text { well as specifica- } \\
\text { tion of nutrition- } \\
\text { al errors }\end{array}$ & $\begin{array}{l}\text { author's } \\
\text { questionnaire } \\
\text { consisting of } \\
123 \text { questions } \\
\text { on nutrition, } \\
\text { physical activity } \\
\text { and the use of } \\
\text { psychoactive } \\
\text { substances }\end{array}$ & $\begin{array}{l}\text { metropolitan ado- } \\
\text { lescents eat more } \\
\text { wholegrain products } \\
\text { than young people living } \\
\text { in the countryside; more } \\
\text { students from the cities } \\
\text { eat breakfast; rural ad- } \\
\text { olescents consume less } \\
\text { dried legumes, but more } \\
\text { often choose whole milk }\end{array}$ & $16-19$ \\
\hline $\begin{array}{l}\text { Sygit K. } \\
\text { (2010) }\end{array}$ & $\begin{array}{l}7 \text { counties of the } \\
\text { West Pomerania } \\
\text { Province }\end{array}$ & - & $\begin{array}{l}\text { assessment of } \\
\text { the correlation } \\
\text { between the } \\
\text { occurrence of } \\
\text { overweight and } \\
\text { obesity in rural } \\
\text { adolescents } \\
\text { and their eating } \\
\text { habits }\end{array}$ & $\begin{array}{l}\text { author's } \\
\text { questionnaire } \\
\text { questionnaire } \\
\text { antropometric } \\
\text { measurements } \\
\text { BMI index }\end{array}$ & $\begin{array}{l}\text { only } 30 \% \text { rated their nu- } \\
\text { trition as good, whereas } \\
\text { as sufficient or bad } 9 \% \\
\text { of the respondents; most } \\
\text { frequently adolescents } \\
\text { consume } 3 \text { or more } \\
\text { meals a day, only three } \\
-56 \% \text {; } 185 \text { out of } 300 \\
\text { were overweight, } 115 \\
\text { obese }\end{array}$ & $15-19$ \\
\hline
\end{tabular}

Source: own elaboration.

Fibre consumed in large amounts is particularly important in preventing diseases arising due to defective nutrition (Jarosz 2010). As Kasperczyk et al. (2007) concluded in their research on the consumption of brown bread and foods rich in fiber by high school students, there is too low proportion of crude, coarse grits in the nutrition of adolescents.

The results of studies by Sochacka and Stypuła (2010) on eating behaviours among the students in Kraków, similarly to the results of Bojan et al. (2010) and Kiciak et al. (2014), revealed a number of irregularities in the nutrition of young people, such as snacking or avoiding main meals. Results of other studies also indicate that not eating early breakfast is factor increasing the risk of overweight and obesity (Timlin 2008, Grøholt et al. 2008). Snacking, declared by most of the surveyed adolescents (including almost 39\% regularly), especially products of low nutritional value (crisps, sweets, sweet carbonated drinks), but with high caloric value can promote excessive weight gain. Overall, less than half of adolescents declared eating five meals a day. Most often teenagers avoided eating afternoon tea and lunch. The authors emphasise that $10 \%$ of students do not eat breakfast at all, $12 \%$ of junior high school students and $13 \%$ of professional technical school students. Eating fast food is also widespread among teenagers, only $13 \%$ do not eat this type of products.

The purpose of the research conducted by Chęcińska et al. (2013) was a comparison of generally understood lifestyle of the adolescents in high school age, coming from both rural and city environment of the Wielkopolskie Province and specification of nutritional mistakes made by them. This research revealed quite interesting results as it turned out that high school students from big cities comply with the healthy eating principles much more often than students from small towns or villages. What is more, they demonstrate a much more advanced knowledge, although still deficient, about human nutrition. And so, for example, the youth, let's call them big city youth, eat more of granary products than the adolescents from villages. Moreover, more people in this group of high school students eat early breakfast. Overall, around $6 \%$ of adolescents eat fast-food every day, but as many as $67 \%$ of them eat it occasionally. Another repeated bad eating habit is snacking between meals. Out of the most popular snacks, students at the level of as high as $70 \%$ choose sweets, and $30 \%$ choose salty or fried products such as salt sticks, potato chips, fast- food. Although the area of physical activity is not a topic of this article, the authors, knowing the crucial role of physical activity for a young body, could not omit presenting the given results. According to the research on the adolescents in Wielkopolskie Province it turns out that almost $70 \%$ of high school students always participate in PE classes, around 19\% usually do, and 5\% attend them occasionally. Nutritional mistakes and low physical activity among young people is an immediate signal to correct this type of lifestyle. Small physical activity is, right next to inappropriate eating habits, one of the main causes of overweight and obesity, particularly among adolescents. (Morin et al. 2013).

Sygit (2010) also decided to deal with the topic of dietary assessment among the adolescents from villages in the West Pomeranian Province area. What is quite interesting is that among all the respondents (n=300) as many as 185 are found to be overweight and 115 of the tested students have obesity. Overweight people indeed were found to be skipping breakfast more often. Highly concerning is the fact that in the group of people with obesity as many as $78 \%$ do not drink milk and $87 \%$ do not eat fruits or vegetables. Data concerning eating 
sweets is disturbing, since $75 \%$ of the adolescents eat them, and within the overweight group this percentage reaches almost 65\%, and in a group with obesity-92\%, respectively. While looking for answers to the question about causes of nutritional mistakes which are this serious among the youth, we may refer to research of Bernekow et al. (2000), which showed a strong relation with the attitude of parents and financial situation of a given family. The environmental factor, including influence of family's lifestyle creates a case to provide health education to not only children and the youth, but also to their immediate family members. The World Health Organization, through the slogan: "Health starts at home", emphasises the role of family in shaping a healthy lifestyle. (Olubiński 2000 after: Zadworna-Cieślak, Ogińska-Bulik 2013, p.106).

\section{The nutritional behaviours of the older adolescents in school age in light of international researches}

The selection of works from countries of varied socio-cultural or economic contexts has been done on purpose. The countries such as Nordic Sweden, Far East China, Arabic Jordan, Egypt and situated on the North American continent Canada, were selected to show that despite the existing differences in language, culture, religion, geography, or political system, they are connected by a common issue of obesity and overweight problems among children and the youth. Numerous publications concerning the nutritional behaviour and its relation to obesity/overweight among children and adolescents around the world are a proof of that. (see: Berkey et al. 2000, Dietz 1998, James et al. 2004, Lytle, Kubik 2003, Malik et al. 2006, Maynard et al. 2003, Morin et al. 2013, Post et al. 2001, Shepherd, Deninnson 1996, Herbold, Frates 2000, Abu-Mweis et al. 2014, Thomas 1991, Timlin et al. 2008, Weaver et al. 1999, WHO 2002, van Lenthe et al. 1996, von Post-Skagegard et al. 2002, Janssen et al. 2005, Ya-Wen Hsu 2011).

In a long-term research of von Post-Skagegard et al. (2002) the objective was to get to know the changes in a nutritional behaviour along the years (1993-1999) among growing up teenagers. Most of the changes in that behaviour were present between the age of 17 and 21 of the youth. What is interesting is that there was no variety in breakfast eating habit found. More than $90 \%$ of teenagers claimed to eat breakfast five or more times a week and only 4-5\% claimed to eat it two or less times a week. However, an increase was noted among both genders in eating fast food products (hamburgers, hot-dogs, kebabs). At the age of 15, this type of food was eaten once a month, while at the age of 21 young men claimed to eat meals like fast food more than three times, while young women more than two times a month. In the first edition of research (adolescents at the age of 15), positive correlation between the frequent consumption of vegetables and parents' level of education (higher education of mother) was found. The authors are of the opinion that at least two factors had an influence on the change in nutritional behaviour over the years among teenagers. The first factor, without a doubt, are changes occurring in relation to food consumption of the Swedish society. In that period there was, for example, a decrease in consumption of fat and milk. Another explanation are the occurring changes determining the lifestyle in a given stage of adolescence, including also the change in nutritional habits. Similar behaviour pattern of young adults is typical among the adolescents in other countries as well, which includes lack of stabilization in nutritional behaviour at adolescence. (Post et al. 2001).

The authors El-Gilany, Elkhawaga (2012), while researching socio-economic determinants of nutritional behaviour of adolescents in Egypt $(n=891)$ came to the following conclusions (Table 2). Percentage of people declaring snacking was quite high, close to the result of Polish research and was at the level of almost 34\%. Quite high was also the percentage of adolescents declaring always eating with their family. In this case a dependency between place of residence of students (higher percentage of students from villages), mother's level of education (housewives or less educated women), and socioeconomic status of family (low or very low) was found. In Egypt people normally eat three meals a day, where dinner is the main meal of a day.

Table 2. Summary of the selected worldwide research on eating behaviours of school-aged adolescents

\begin{tabular}{|l|c|c|c|c|c|c|}
\hline $\begin{array}{c}\text { First } \\
\text { author }\end{array}$ & $\begin{array}{c}\text { Place } \\
\text { of research }\end{array}$ & $\begin{array}{c}\text { Year of } \\
\text { research }\end{array}$ & \multicolumn{1}{c|}{ Aim of research } & $\begin{array}{c}\text { Measuring } \\
\text { tool }\end{array}$ & $\begin{array}{c}\text { Age } \\
\text { (in } \\
\text { years) }\end{array}$ \\
\hline $\begin{array}{l}\text { El-Gilany } \\
\text { A.H. et al. } \\
\mathbf{( 2 0 1 2 )}\end{array}$ & Egypt & 2010 & $\begin{array}{l}\text { analysis of econom- } \\
\text { ic and social factors } \\
\text { having influence on } \\
\text { nutritional behaviour } \\
\text { among the youth }\end{array}$ & $\begin{array}{l}\text { survey ques- } \\
\text { tionnaire pre- } \\
\text { pared by the } \\
\text { researchers }\end{array}$ & $\begin{array}{l}\text { around 46\% of people eat three } \\
\text { meals a day, 72\% eat breakfasts, } \\
\text { 93\% eat dinner, and 95\% eat } \\
\text { supper every day; snacks are } \\
\text { consumed by around 34\% of } \\
\text { students. Shared meal with the } \\
\text { family is declared by as much as } \\
\text { 62.5\% }\end{array}$ \\
\hline
\end{tabular}




\begin{tabular}{|c|c|c|c|c|c|c|}
\hline $\begin{array}{l}\text { von Post- } \\
\text { Skagegard } \\
\text { M. et al. } \\
(2002)\end{array}$ & Sweden & $\begin{array}{c}1993- \\
1999\end{array}$ & $\begin{array}{l}\text { Recognition of the } \\
\text { changes happening in } \\
\text { nutritional habits over } \\
\text { the years in relation to } \\
\text { age, gender, religion, } \\
\text { and socio-economic } \\
\text { background }\end{array}$ & $\begin{array}{l}\text { Food Frequen- } \\
\text { cy Question- } \\
\text { naire (FFQ) } \\
\text { concerning } \\
\text { frequency of } \\
\text { eating meals, } \\
\text { nutritional } \\
\text { behaviour, so- } \\
\text { cio- economic } \\
\text { status of } \\
\text { students and } \\
\text { their families } \\
\end{array}$ & $\begin{array}{l}\text { nutritional behaviour changes } \\
\text { significantly throughout ado- } \\
\text { lescence along with the change } \\
\text { of lifestyle; the author found a } \\
\text { positive correlation between } \\
\text { increased consumption of veg- } \\
\text { etables and pasta, and mother's } \\
\text { level of education (higher) }\end{array}$ & $15-21$ \\
\hline $\begin{array}{l}\text { Abu- } \\
\text { Mweis } \\
\text { S.S et al. } \\
(2014)\end{array}$ & Jordan & 2009 & $\begin{array}{l}\text { Study of phenomenon } \\
\text { of overweight and } \\
\text { obesity commonness, } \\
\text { lifestyle patterns: } \\
\text { nutritional behaviour, } \\
\text { physical activity (*PA) } \\
\text { or sedentary behav- } \\
\text { iours }\end{array}$ & $\begin{array}{l}\text { survey ques- } \\
\text { tionnaire pre- } \\
\text { pared by the } \\
\text { researchers } \\
\text { used earlier } \\
\text { in ATLS-Arab } \\
\text { Teens Life- } \\
\text { style Study }\end{array}$ & $\begin{array}{l}\text { high percentage of the adoles- } \\
\text { cents in Jordan shows un- } \\
\text { healthy, undesirable behaviour; } \\
\text { dominance of overweight and } \\
\text { obesity occurrence was higher } \\
\text { among boys, } 16.1 \% \text { and } 9.6 \% \text {, } \\
\text { respectively, than among girls, } \\
12.6 \% \text { and } 4.3 \% \text {, respectively; } \\
\text { lest than } 1 / 3 \text { of teenagers ate } \\
\text { breakfast, fruits and vegetables } \\
\text { every day }\end{array}$ & $14-20$ \\
\hline $\begin{array}{l}\text { Ya-Wen } \\
\text { Hsu et al. } \\
(2011)\end{array}$ & China & 2002 & $\begin{array}{l}\text { Study of factors having } \\
\text { influence on over- } \\
\text { weight of adolescents } \\
\text { in China }\end{array}$ & $\begin{array}{l}\text { Youth Risk } \\
\text { Behaviour } \\
\text { Survey } \\
\text { Questionnaire } \\
\text { (YRBSS), - }\end{array}$ & $\begin{array}{l}\text { relations between overweight of } \\
\text { adolescents in China and their } \\
\text { sedentary behaviours, } \\
\text { time spent in front of a TV, } \\
\text { (computer) were shown, high } \\
\text { school students were over- } \\
\text { weight more rarely than those } \\
\text { from Junior High School }\end{array}$ & $15-18$ \\
\hline $\begin{array}{l}\text { Morin P. et } \\
\text { al. (2013) }\end{array}$ & Canada & - & $\begin{array}{l}\text { Study of relationship } \\
\text { between nutritional } \\
\text { behaviour and physical } \\
\text { activity }\left({ }^{*} \mathrm{PA}\right)\end{array}$ & $\begin{array}{l}\text { survey } \\
\text { questionnaire } \\
\text { prepared by } \\
\text { the research- } \\
\text { ers, studying } \\
\text { nutritional } \\
\text { behaviour, } \\
\text { physical activ- } \\
\text { ity }(* \mathrm{PA})\end{array}$ & $\begin{array}{l}\text { physically active adolescents } \\
\text { were eating fruits, vegetables, } \\
\text { and full-grain bread, as well as } \\
\text { eating breakfast more keenly } \\
\text { and more frequently. }\end{array}$ & $13-17$ \\
\hline
\end{tabular}

\footnotetext{
* PA- Physical Activity
}

Source: own elaboration.

The research showed that natural behaviour of the adolescents is avoiding certain meals during a day. More than $38 \%$ of adolescents claimed to skip one or two meals a day. Breakfast, according to the Polish research as well (ed. Chęcińska et al. 2013, Sochacka-Tatara, Stypuła 2010, Kiciak et al. 2014), turned out to be the most frequently skipped meal.

Moreover, the Canadian adolescents (Morin et al. 2013) showed a decrease in frequency of eating breakfast. The older they got the more a frequency of eating this meal decreased. Children at an elementary school age were characterised by a very high percentage (more than 95\%) of eating breakfast every day, while, in high school it was way lower (28\% in a group of 13 year olds, 34\% among 17 year olds skipped at least one breakfast). The authors seek the cause of this behaviour in lack of time among young people, morning activities concerned with going to school, irregular class schedule or lack of morning appetite (Leleiko et al. 1995, Fung et al. 1997, Graham, Uphold 1992, Miller, Maropis 1998 after: El-Gilany Elkhawaga 2012). In a Canadian research a decrease was noted in percentage of the adolescents eating vegetables, fruits, full-grain bread, and milk, every day. Variety based on gender, age, started to be visible in a group of the 13-year olds, particularly among girls, who eat vegetables and fruits much more often than boys. On the other hand, consumption of sugar-sweetened drinks was found to be increasing along with the age, especially in a group of boys. Fruit juices were popular among $34 \%$ in a group of 13 year olds, but among 17 year olds they were consumed already by $65 \%$. Approximately 
around $40 \%$ of Canadian children at the age of 5-11 ate a meal in a fast-food type of restaurant, while in a group of 17 year olds this percentage increased to $60 \%$. Since the purpose of the research was also the assessment of physical activity, it is worth to show the obtained results in this area. Overall, around $41 \%$ of adolescents claim to get engaged in 60 minutes physical activity during a day. Where in half of the respondents in a group of boys $(49 \%)$ reached the recommended level of physical activity and only one third in a group of girls (34\%) reached it.

The research in a representative trial of the adolescents from Jordan by Abu-Mweis, et al. (2014) aimed to, similarly to the Canadian research, assess not only the nutritional behaviour, but also physical activity and sedentary behaviours. This work is a part of the ATLS-Arab Teens Lifestyle Study (Table 2). Consumption of sweets was much higher among girls than boys, while frequency of eating fast-food kind of products and sugarsweetened fuzzy drinks was higher among boys. What is interesting is the fact that eating breakfasts (overall $3.3 \pm 2.6$ times a week) and frequency of drinking milk (overall $4.0 \pm 2.5$ times a week) were higher among boys than girls.

High frequency of consumption was characteristic for products like fries, potato chips (overall $3.9 \pm 2.4$ times a week), cookies, donuts (overall 3.4 \pm 2.3 times a week), and candies and chocolate (overall $4.4 \pm 2.3$ times a week). Most of the teenagers from Jordan showed unhealthy eating habits characterised by low frequency of eating fruits, vegetables and milk, and high frequency of consuming fats and sugar. It is also worth to mention the stated low level of physical activity, and high percentage of sedentary behaviours, especially among girls.

Analysis of factors influencing occurrence of overweight among the adolescents from China (Ya-Wen Hs et al. 2011) brought quite surprising conclusions, which differed from most of study results of researchers from the Western cultures (Ogden et al. 2007). The first Chinese paradox is a positive correlation between the occurrence of overweight among the adolescents and education and high salary of their parents. The youth, whose parents had higher or secondary education, showed bigger tendency for overweight than those, whose parents did not graduate from high school. Unhealthy changes in a lifestyle and gaining weight are mainly a domain of richer families, who own a car, spend more time on sedentary behaviours, consume high energy foods (e.g. meat or processed products), as well as being typical for the West fast-food type of products (much more expensive that typical Chinese food). It is worth noticing that China nowadays experiences two processes, one is a huge modernization of the country, the other is bringing in the patterns of a Western culture, so called "Westernization" (Wang 2001 za: Ya-Wen Hsu et al. 2011). The logical outcome of these processes is adapting by richer adolescents bad nutritional habits of western civilization, such as eating meals in a fast- food type of restaurant, which has become some sort of trend in China. (Yan 2008 for: Ya-Wen Hsu et al. 2011). Another paradox is the relationship between frequent consumption of vegetables and the risk of overweight occurrence. This data definitely does not overlap with results of the research conducted among the western culture youth. (Epstein et al. 2001, WHO/FAO 2003 for: Ya-Wen Hsu et al. 2011). An explanation for this phenomenon could be a way of preparing vegetables specific for the Chinese cuisine, which is usually frying them in a deep oil or stir frying them.

Those processes occurring in the rich Chinese adolescents lifestyle are extremely interesting because of the existence of certain analogies to processes occurring in a Polish adolescents lifestyle. Teenagers from Poland also took over, during the period of the political system transformation, and are still taking over many unhealthy, associated with western culture and thought of as better, lifestyle patterns. These analogies would definitely need further sociological research in this direction.

\section{Conclusions}

In light of the presented results of selected domestic researches and researches from other countries around the world, constant monitoring of the way the teenage people eat seems to be of a particular importance. Extremely important is nutrition education delivered in schools. Teenagers in such an important period of their lives, when so many changes occur on so many levels, will want to change their own nutritional habits as well. Changes in nutritional behaviour can go in many directions, not always good for life and health of a young person. It is important for teenagers to see many benefits coming from adapting healthy eating habits, and be aware of consequences in health coming from nutritional deficiency that may come in later stages of their lives. Then perhaps they will follow without a protest the school and social health promotion programs.

The results of analysed research papers regarding the nutritional behaviours of the adolescents confirm the presence of variation in eating choices, based on the gender. Girls value what nutrition means for health through eating more healthy products, such as fruits and vegetables. The researches also show that girls, in comparison to boys, are characterised by lower frequency of behaviours which are risky for health (http://www.studio47. com.pl/wartosczdrowia.... 17.06.2015). They tend to eat meals irregularly, and often do not eat breakfasts and 
suppers, but do not compensate it by eating fast-food type of products, like boys do. (Hoglund et al. 1998 for: von Post-Skagegard et al. 2002).

Limitation in number of meals during a day, as well as having too long breaks in between, fosters the adolescents to eat many different kinds of snacks of low nutritional value, like sweets or potato chips. The issue of snacking between meals is signalised by a number of authors of the analysed research works, and the results achieved by them are varied (Kiciak et al. 2014, Sochacka-Tatara, Stypuła 2010). Skipping breakfast and lunch (see: Chęcińska, et al. 2013, Sochacka-Tatara, Stypuła 2010, Kiciak et al. 2014, El-Gilany 2012, Abu-Mweis et al. 2014, Morin et al. 2013), which gives to a body around 35-45\% of energy (Bojar et al. 2010) is another pressing problem in a nutritional behaviour among the youth, which could be a factor increasing the risk of overweight and obesity occurrence (Timlin 2008, Grøholt et al. 2008). Many assumptions are also confirmed by the relation between frequent consumption of sugar-sweetened fuzzy drinks and increase in risk of obesity occurrence (Malik et al. 2006, James et al. 2004).

The way of eating is conditioned by a level of economic growth in a given country. What influences it is tradition, financial level, education level, availability and prices of food products, advertisement. The right consumption is not only quantity but also quality of eaten meals.

\section{References:}

1. Abu-Mweis S.S., Tayyem R.F., Bawadi H.A., Musaiger A.O., Al-Hazzaa M.H. (2014), Eating habits, physical activity, and sedentary behaviors of Jordanian adolescents' residents of Amman. Mediterranean Journal of Nutrition and Metabolism 7, p. 67-74.

2. Berkey C.S., Rockett H.R., Field A.E., i in. (2000), Activity, dietary intake, and weight changes in a longitudinal study of preadolescent and adolescent boys and girls. Pediatrics 105, E56.

3. Bernekow R., Rasmussen V., Rivett D., (2000), The European Network of health Promoting School - an alliance of health, education and democracy. Health Educ, 2, p. 61-69.

4. Bojar I., Wojtyła A., Biliński P., Wojtyła K. (2010), Zwyczaje żywieniowe młodzieży w Polsce. Zagadnienia Zdrowia Publicznego. Medycyna Ogólna 16 (XLV), p. 547-557.

5. Buczak A. (2013), Zachowania żywieniowe gimnazjalistów i studentów w kontekście wpływu społecznego. Medycyna Ogólna i Nauki o Zdrowiu, vol. 19, no. 2, p. 116-122.

6. Chęcińska Z., Krauss H., Hajduk M., Białecka-Grabarz K. (2013), Ocena sposobu żywienia młodzieży wielkomiejskiej i obszarów wiejskich. Prob Hig Epidemiol 94(4), p. 780-785.

7. Dietz W.H. (1998), Health consequences of obesity in youth: childhood predictors of adult disease. Pediatrics 101, p. $518-525$.

8. El-Gilany A-H., Elkhawaga G. (2012), Socioeconomic determinants of eating pattern of adolescent students in Mansoura, Egypt. Pan African Medical Journal. p. 13-22.

9. Grøholt E.K., Stigum H., Nordhagen R. (2008), Overweight and obesity among adolescents in Norway: cultural and socio-economic differences. JPublicHealth 30(3), p. 258-265.

10. Harton A. (2013), Zachowania żywieniowe dzieci w Polsce. [In:] J. Szymborski, W. Zatoński (ed.), Zdrowie Publiczne. Monografie Tom II. Zdrowie dzieci i młodzieży w wymiarze socjomedycznym. Wyd. Wszechnica Polska, Szkoła Wyższa w Warszawie, p. 115-133.

11. Herbold N.H., Frates S.E. (2000), Update of nutrition guidelines for the teen: trends and concerns. Curr. Opin. Pediatr. 12, p. 303-309.

12. James J., Thomas P., Cavan D., Kerr D. (2004), Preventing childhood obesity by reducing consumption of carbonated drinks: cluster randomised controlled trial. BMJ, 328, p. 1237-1239.

13. Janssen I., Katzmarzyk P.T., Boyce W.F., Vereecken C., Mulvihill C., Roberts C., Currie C., Pickett W., and The Health Behaviour in School-Aged Children Obesity Working Group (2005), Comparison of overweight and obesity prevalence in school-aged adolescents from 34 countries and their relationships with physical activity and dietary patterns. The International Association for the Study of Obesity. Obesity Reviews 6, p. 123-132.

14. Jarosz M. (2010), Praktyczny podręcznik dietetyki. Warszawa: Instytut Żywności i Żywienia.

15. Kasperczyk J., Jośko J., Bilska J. (2007), Sposób odżywiania się oraz wybrane czynniki zdrowego stylu życia wśród młodzieży licealnej. Probl Hig Epidemiol. 88 (2), p. 157-161.

16. Kiciak A., Całyniuk B., Grochowska-Niedworok E., Kardas M., Dul L. (2014), Zachowania żywieniowe młodzieży z województwa śląskiego. Medycyna Ogólna i Nauki o Zdrowiu, vol. 20, no. 3, p. 296-300.

17. Lustig R.H. (2006), Childhood obesity: behavioral aberration or biochemical drive? Reinterpreting the First Law of Thermodynamics. Nat Clin Pract Endocrinol Metab 2, p. 447-458.

18. Lytle L.A., Kubik M.Y. (2003), Nutritional issues for adolescents. Best Pract Res Clin Endocrinol Metab 17, p. 177-189. 
19. Łuszczyńska A. (2004), Zmiana zachowań zdrowotnych. Dlaczego dobre chęci nie wystarczą? Gdańskie Wydawnictwo Psychologiczne, Gdańsk.

20. Maffeis C. (2000), Aetiology of overweight and obesity in children and adolescents. Eur J Pediatr,159, p. 35-44.

21. Malik V.S., Schulze M.B., Hu F.B. (2006), Intake of sugar-sweetened beverages and weight gain: a systematic review. Am J Clin Nutr, 84(2), p. 274-288.

22. Maynard M., Gunnell D., Emmett P. (2003), Fruit, vegetables, and antioxidants in childhood and risk of adult cancer: the Boyd Orr cohort. J Epidemiol Community Health 57, p. 218-225.

23. Mazur J., Małkowska-Szkutnik A. (2011), Wyniki badań HBSC 2010. Raport techniczny. Instytut Matki i Dziecka, Warszawa.

24. Morin P., Turcotte S., Perreault G. (2013), Relationship between eating behaviors and physical activity among primary and secondary school students: results of a cross-sectional study. J Sch Health. 83, p. 597-604.

25. Must A., Barish E.E., Bandini L.G. (2009), Modifiable risk factors in relation to changes in BMI and fatness: what have we learned from prospective studies of school-aged children? Int J Obe. 33, p. 705-715.

26. Post G.B., de Vente W., Kemper H.C.G., Twisk J.W.R. (2001), Longitudinal trends in and tracking of energy and nutrient intake over 20 years in a Dutch cohort of men and women between 13 and 33 years of age: The Amsterdam growth and health longitudinal study.Br J Nutr,85, p.375-385.

27. Shepherd R., Dennison C.M. (1996), Influences on adolescent food choices. Proc. Nutr. Soc. 55, p. 345-357.

28. Sochacka-Tatara E., Stypuła A. (2010), Zaburzenia odżywiania wśród uczniów szkół krakowskich - część ogólnopolskich badań zaburzeń odżywiania wśród młodzieży. Prob Hig Epidemiol 91(3), p.591-595.

29. Sygit K. (2010), Nieprawidłowości żywieniowe zagrożeniem zdrowia populacji dzieci i młodzieży. Zdr Publ $120(2)$, p. $132-135$.

30. Thomas J. (1991), Food choices and preferences of schoolchildren. Proc. Nutr. Soc. 50, p. 49-57.

31. Timlin M.T., Pereira M.A., Story M., Neumark-Sztainer D. (2008), Breakfast eating and weight change in a 5-year prospective analysis of adolescents: Project EAT(Eating Among Teens). Pediatrics, 121(3), p. 638-645.

32. Trudeau F., Laurencelle L., Shephard R.J. (2004), Tracking of physical activity from childhood to adulthood. Med Sci Sports Exerc,36, p. 1937-1943.

33. Warburton D.E.R., Nicol C.W., Bredin S.S.D. (2006), Health benefits of physical activity: the evidence. Can Med Assoc J,174, p. 801-809.

34. Weaver C.M., Peacock M., Johnston C.C. Jr. (1999), Adolescent nutrition in the prevention of postmenopausal osteoporosis. J. Clin. Endocrinol. Metab. 84, p. 1839-1843.

35. Wojtyła A., Kapka-Skrzypczak L., Paprzycki P., Diatczyk J., Bylina J. (2011), Zachowania Zdrowotne Młodzieży. Raport. Instytut Medycyny Wsi. Lublin.

36. World Health Organization (2002), Diet, Nutrition and the Prevention of Chronic Diseases. WHO/FAO Expert Consultation.: 916 Geneva: WHO.

37. van Lenthe F.J., Kemper C.G., van Mechelen W. (1996), Rapid maturation in adolescence results in greater obesity in adulthood: the Amsterdam Growth and Health Study. Am J Clin Nutr 64, p. 18-24.

38. von Post-Skagegard M., Samuelson G., Karlstro B., Mohsen R., Berglund L., Bratteby L-E (2002), Changes in food habits in healthy Swedish adolescents during the transition from adolescence to adulthood. European Journal of Clinical Nutrition 56, p. 532-538.

39. Zadworna-Cieślak M., Ogińska-Bulik N. (2011), Zachowania zdrowotne młodzieży-uwarunkowania podmiotowe i rodzinne. Wyd. Difin SA, Warszawa.

40. Ya-Wen Hsu, Anderson Johnson C., Chih-Ping Chou, Unger J.B., Ping Sun, Bin Xie, Palmer H.P., Gallaher P.E., Spruijt-Metz D. (2011), Correlates of Overweight Status in Chinese Youth: An East-West Paradox. Am J Health Behav. 35(4), p. 496-506.

\section{Internet websites:}

41. http://www.studio47.com.pl/wartosczdrowia/praca_pogladowa.html access: 17.06.2015

42. http://www.nuigalway.ie/hbsc/documents/badania_nad_zachowaniami_zdrowotnymi_mlodziezy_ szk__2012.pdf access: 17.06.2015

Submitted: 22.07.2015

Accepted: 13.11.2015 